\title{
The Institutional and Socio-Economic Constraints to Smallholder Tobacco Production and Marketing in Mount Darwin District of Zimbabwe: The Value Chain Approach
}

\author{
Joseph Muroiwa* Abbyssinia Mushunje Tawedzegwa Musitini \\ Department of Agricultural Economics and Extension, University of Fort Hare. P Bag X1314, Alice 5700, \\ Republic of South Africa
}

\begin{abstract}
This research was financed by the Govan Mbeki Research and Development Centre.
Abstract

This study used the value chain approach to identify the institutional and socio-economic constraints to tobacco production and marketing in Mount Darwin District; Zimbabwe. Three hundred and eighty farmers were randomly sampled for the study. Key informant interviews were used to collect data from input suppliers, contractors, buyers, auction floors, the Tobacco Industry Marketing Board, EMA and government extension staff. Data was analysed using descriptive statistics and the Pairwise ranking matrix. Results from the study identified shortage of foreign currency and high transport costs as the major constraints affecting input suppliers. Dry spells, labour shortages, high inputs costs, fuel shortages, pests were some of the farmers' constraints to tobacco production. Some of the major marketing constraints affecting the smallholder farmers included low producer prices, high transport costs, theft in transit and exploitative prices offered by tobacco merchants. Auction companies cited viability challenges due to declining tobacco volumes sold through auction floors. Tobacco contractors cited side-marketing, diversion of tobacco inputs by farmers and high operating costs as major constraints affecting their operations. The results from the study show that there are a lot of constraints affecting the smallholder tobacco chain and these can be addressed through collaboration among the chain stakeholders
\end{abstract}

Keywords: institutional constraints; tobacco value chain; Mount Darwin District; smallholder farmers.

DOI: $10.7176 / \mathrm{JESD} / 10-7-09$

Publication date: April $30^{\text {th }} 2019$

\section{INTRODUCTION}

Tobacco is the "lifeblood of Zimbabwe's economy" accounting for 10-43\% of the country's gross domestic product (Lown et al., 2016). Over 90,000 of Zimbabwe's smallholder farmers are employed in the tobacco sector thereby making the industry one of the single largest employers in the country (TIMB, 2018). Zimbabwe exports $98 \%$ of the tobacco crop making it the biggest foreign currency earner (TIMB, 2018). Despite the crucial role played by tobacco in Zimbabwe's agricultural development, the sector faces a plethora of socio-economic constraints which if unaddressed might threaten the resilience and sustainability of the sector. Smallholder tobacco farmers continue to battle with socio-economic and institutional challenges. The average tobacco yield per hectare plunged from over 2700kgs prior to the Fast Track Land Reform Program (FTLRP) in 2000 to the lowest figures of $790 \mathrm{~kg} / \mathrm{ha}$ in 2008/9 season (TIMB, 2015). Although the sector is showing signs of recovery, the average yields per ha of less than $2000 \mathrm{~kg}$ recorded during the 2015 and prior seasons still remain lower than $2700 \mathrm{~kg} / \mathrm{ha}$ recorded by the former large scale commercial farmers prior to FTLRP. Despite the increase in the number of tobacco merchants in Zimbabwe from three in 2000 to twenty-one as at the 2015 marketing season, it is worrisome that the industry still faces institutional challenges with some farmers contemplating of quitting tobacco production. Instead of registering a steady growth, the sector saw the number of registered tobacco farmers declining by $8 \%$ between 2014 and 2015 resulting in a drop in production between these successive seasons (TIMB, 2015). It can be argued that although Zimbabwe has many merchants in the tobacco value chain, farmers still face challenges in the production and marketing of tobacco.

A reduction in tobacco yields per hectare and total national output saw Zimbabwe's global tobacco export market share declining from 10\% in 2000 to $5 \%$ in 2014 (Goger et al, 2014). The beginning of most marketing seasons have been characterised by standoffs between tobacco farmers and buyers over low producer prices (Mhlanga, 2016; The Herald, 2016). There is tension and lack of trust amongst farmers, buyers and tobacco floors with farmers accusing buyers of teaming up with tobacco floors to pay low prices and then reselling the tobacco at higher prices (The Herald, 2016). There are some merchants ('A' class buyers) who buy and resell all the tobacco they buy from the farmers. It can be argued that the only reason why the ' $\mathrm{A}$ ' class buyers remain in business is because they are buying tobacco from the farmers at artificially low prices to enable them to put a mark-up and resell the tobacco to the Multi-National Corporations. Tobacco graders have been accused of demanding money to peg tobacco bales at favourable prices. On the other hand, tobacco floors have blamed the farmers of failing to meet high tobacco quality standards and have cited that as the main reason for paying low prices. Farmers on several occasions have withheld the crop in protest thereby causing interruptions in the buying process. 
According to (Kirsten et al., 2009), too little analysis of institutional processes and constraints in agricultural development has been done in the past. Early writings in development economics largely attributed underdevelopment to deficiencies in factor endowments, specifically physical and human capital, and to the lack of technology change (Dorward et al., 2009). The previous studies have regarded institutions as given (Dorward et al., 2009). This study uniquely uses the value chain approach to analyse institutional and socio-economic constraints to tobacco production and marketing in Zimbabwe thereby contributing in addressing the current existing knowledge gap.

The value chain concept was defined as a sequence of activities performed on a commodity from its production, trading, processing, export and consumption including the disposal of end products (Prowse \& MoyerLee, 2013: Kaplinsky \& Morris, 2001). In Zimbabwe, the tobacco value chain activities include inputs production, crop production, grading, marketing, processing, distribution, exporting, consumption and disposal of end products. The value chain actors comprised of inputs suppliers, farmers, buyers, processors, auction and contract floors, marketers, consumers as well as value chain supporters and regulators.

This study gives an outline of how the tobacco value chain operated and the bottlenecks that affected the different value chain actors participating in tobacco production and marketing in Zimbabwe. It also scrutinized the inputs supply process, production, marketing, manufacturing, processing and distribution. The roles and responsibilities of the value chain actors and regulators will be outlined including the socio-economic constraints faced at each and every stage of the value chain.

\section{Literature Review}

Studies conducted in Algeria's olive oil value chain cited poor agricultural practices, weak institutional environment, lack of market transparency, market uncertainties and lack of quality control as some of the major bottlenecks undermining the development of the value chain (Boudi et al., 2016). The accession was also supported by (Popp, 2013) who posited that unclear regulatory and policy environments, high illiteracy levels and lack of knowledge and skills are among other institutional and socio-economic challenges affecting most agricultural value chains in Africa.

Sambuo (2014) carried out a study on smallholder tobacco producers in Urambo District of Tanzania and revealed that limited access to capital and high dependence on traditional farming methods were among major constraints to the performance of the tobacco value chain. The research findings contrasted with Mwimo et al., (2016) who revealed that although the tobacco value chain has some institutional arrangements such as contract farming, that has not helped smallholder farmers to access credit from financial institutions in Tanzania.

Studies carried by Eaton et al., (2008) in Tanzania's fresh fruit vegetable value chain revealed that weak institutional environment and high transactions costs emanating from too many road blocks and illegitimate controls by the state police for bribes were among the major institutional challenges affecting Tanzania's fresh vegetable value chain. This contrasted with findings from Uganda where it was revealed that institutional norms such as patriarchy, lack of proper coordination within responsible ministries were the constraints affecting the performance of the agricultural sector (Bategeka et al., 2013).

In South Africa, Cloete (2013): Van Schalkwyk et al., (2009) revealed that most agricultural projects targeted at agricultural development in South Africa's North West Province recorded low success rates despite government's effort to support the sector. The research findings showed that lack of institutional support in terms of improved transport infrastructure and smallholder farmer access to finance were some of the constraints affecting agriculture. Sikwela \& Mushunje (2013) also attributed lack of agricultural development in South Africa's Eastern Cape and KwaZulu Natal Provinces to institutional obstacles like lack of technical skills, high marketing and transaction costs, and lack of access to information. The research revealed that although governments strive to improve access to markets and funding, meaningful development in values chains may not be achieved if there are lack of skills, education, enough water for agricultural use and enough support services from government agents. It was also noted that in some cases, some of the resources provided by government could not reach the intended beneficiaries.

\subsection{MATERIALS AND METHODS.}

\subsection{The Study Area}

The study was conducted in Mount Darwin District in Zimbabwe. Mount Darwin District is one of the eight districts in Mashonaland Central Province, Zimbabwe where tobacco is the major cash crop grown by the smallholder farmers. According to the statistics released by the TIMB (2018), the district produced 13000 tons out of 53000 tons produced in the Mashonaland Central Province (25\%) in the 2016/17 season. Tobacco is commonly grown in the southern parts of the districts as shown on Figure 1 below. 


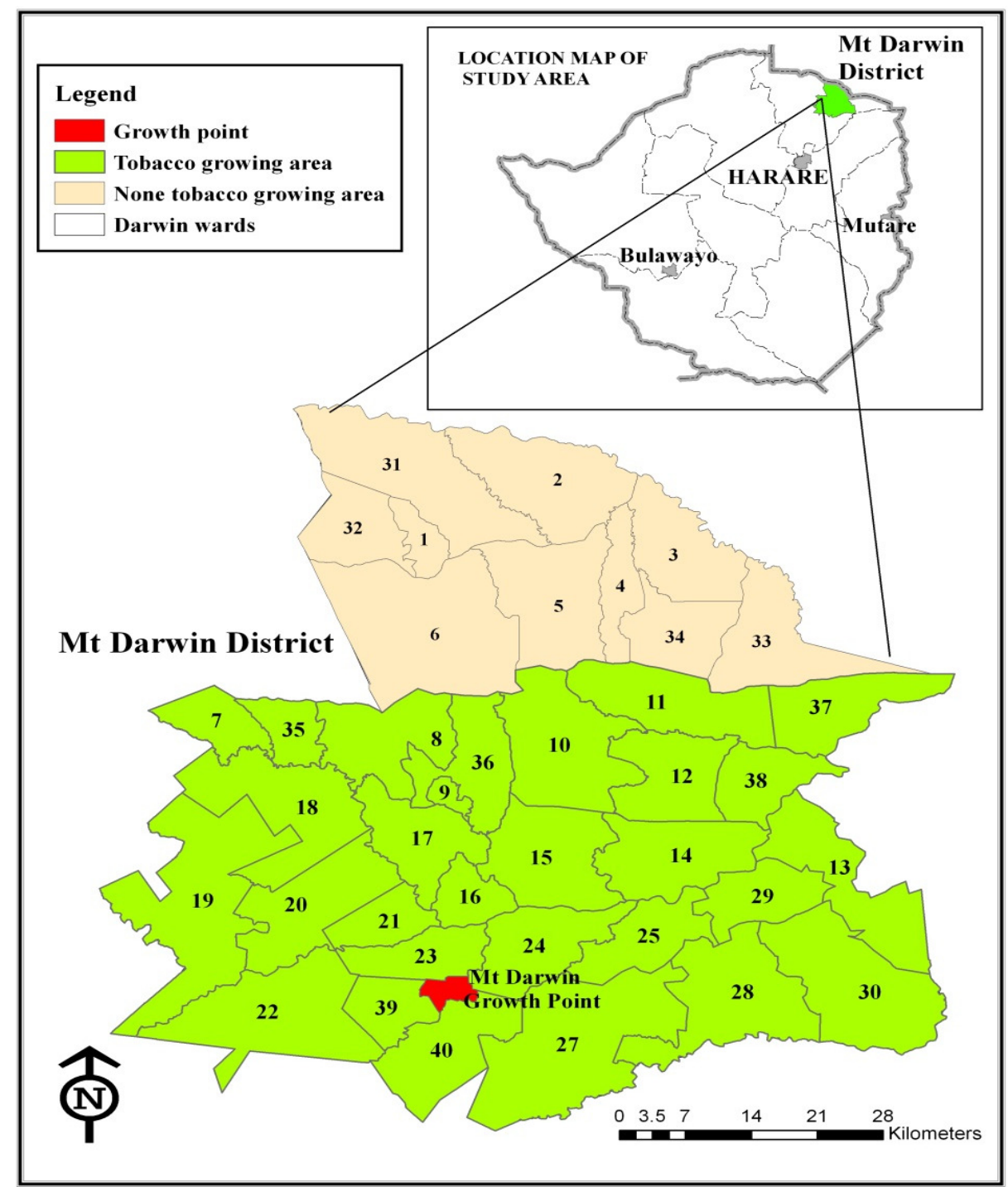

Figure 1. Location map of Mount Darwin District showing tobacco growing areas. Source: Bindura University of Science Education (2018)

\subsection{Methodology}

\subsubsection{Method of data collection, primary and secondary data sources}

Stratified random sampling was used for the selection of 380 tobacco smallholder farmers using the proportion: $20 \%$ from those producing under auction and $80 \%$ producing under contract arrangements. This was because $20 \%$ of the farmers produced and marketed their crop under auction whilst $80 \%$ produced and marketed under contract (TIMB, 2018). Data was collected from the tobacco value chain stakeholders starting with inputs suppliers, farmers, contractor, buyers, floors (auction and contract), the Tobacco Industry Marketing Board, government extension staff, Environment Management Agency (EMA), banks and contractors. The sample sizes were as shown on Table 1 below. 
Table 1: Summary of sample sizes for the value chain stakeholders

\begin{tabular}{|c|c|c|c|c|c|}
\hline $\begin{array}{l}\text { Value-chain } \\
\text { stakeholder }\end{array}$ & $\begin{array}{l}\text { Population } \\
\text { study area }\end{array}$ & in & Location found & $\begin{array}{l}\text { Respondents } \\
\text { sampled }\end{array}$ & Method of collecting data \\
\hline Farmers & 6688 & & Local & 380 & $\begin{array}{l}\text { Questionnaire, Focus group } \\
\text { discussions }\end{array}$ \\
\hline Input suppliers & 4 & & Local; Bindura & 4 & $\begin{array}{l}\text { Key Informant interviews } \\
\text { (KII) }\end{array}$ \\
\hline Contractors & 8 & & Local, Harare & 8 & KII \\
\hline Buyers & 8 & & Local, Harare & 8 & KII \\
\hline EMA & 1 & & Local & 1 & KII \\
\hline Banks & 3 & & Local; Bindura & 3 & KII \\
\hline Agritex Officers & 90 & & $\begin{array}{l}\text { Wards, district } \\
\text { offices }\end{array}$ & 5 & KII \\
\hline TIMB & 1 & & Bindura; Harare & 1 & KII \\
\hline EMA & 1 & & Local & 1 & KII \\
\hline Floors & 3 & & Harare & 3 & KII \\
\hline
\end{tabular}

Source: Survey data (2018)

The farmer sample size was calculated using Yamane's formula at 95\% confidence level as illustrated below (Yamene, 1967).

$$
\begin{array}{ll}
\text { Where } & \mathrm{n}=\frac{\mathrm{N}}{1+\mathrm{Ne}^{2}} \\
\mathrm{n} & =\text { sample size } \\
\mathrm{N} & =\text { population size }(6688) \\
\mathrm{e} & =\text { allowable error of } 5 \% \text { (level of precision) }
\end{array}
$$

Basing on the above formula, a sample size of 377 farmers was obtained and rounded up to 380.

Questionnaires comprising mostly of closed-ended questions were the main instruments for collecting data from smallholder farmers while Focus Group Discussions (FGDs) with Master Farmers [those with master farmer certificates] were complementary approaches to data collection. The questionnaires were used to collect demographic information (sex, age category, household composition) and solicited for information on the production and marketing of tobacco as well as socio-economic and institutional constraints to tobacco production and marketing. Two focus group discussions (FGDs) were conducted within the study areas (1 in Mudzengere Communal Area and 1 in Tsakare Fast Track Resettlement area). Key informant interviews were used to collect data from inputs suppliers, TIMB, tobacco contractors, lead farmers, banks and extension staff from both Agritex and contractors. Due to the small population sizes of the other chain stakeholders, it was not necessary to take samples. The value chain approach was used to investigate the socio economic and institutional factors affecting production and marketing of tobacco. The compositions of the respondents varied in terms of gender and age categories. The FGDs was facilitated by one researcher and one note-taker. Secondary data was mainly collected from TIMB annual statistical reports, farmer bulletins and reports from tobacco contractors. Most of the data was collected between Mid-March and July 2018 when the tobacco selling season was in full swing. Data was collected by 6 trained enumerators and captured on SPSS.

\subsubsection{Data Analysis}

The Pairwise Ranking Matrix (Gay et al., 2016) was used to rank the production and marketing constraints facing the tobacco value chain. Data was also analysed using both SPSS and Microsoft Excel. The next section takes us through the research findings and discussions.

\subsection{RESULTS AND DISCUSSIONS}

\subsubsection{Inputs production and supply}

The inputs required for tobacco production included seed, seedlings, fertilisers (basal and top dressing), pesticides, herbicides, fungicides, fire-wood, coal, labour, extension and working capital. The study noted that the Tobacco Research Board (TRB) enjoyed monopoly over tobacco seed production. The TRB was responsible for undertaking research and development on existing and new varieties. The study identified that distribution of the tobacco seedlings from TRB to the farmers was done through four main channels namely:

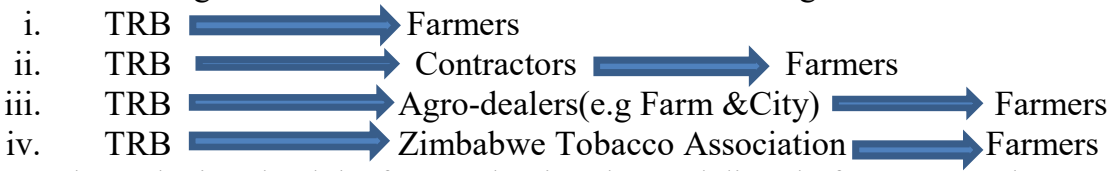

Channel 1 involved the farmers buying the seed directly from TRB. The second channel involved contractors buying the seed from TRB. The contractors then distribute the seed to the farmers producing under contract farming arrangements. The third channel involved the farmers accessing the tobacco seed through reputable agro- 
dealers such as Farm \& City which have branches in Bindura and Mvurwi. The fourth channel involved distribution through farmer organisations such as the Zimbabwe Tobacco Association

The study identified four major fertiliser companies that provided blends and compound fertilisers. These companies were the Zimbabwe Fertilizer Company (ZFC), Windmill, Superfert, and Omnia. There was a monopoly in the production of nitrogenous fertilisers in Zimbabwe where-by Sable Chemicals was the sole producer of the input. The raw materials like phosphates used in fertiliser production were locally mined from Dorowa mine whilst other elements like ammonia, and potash were imported. The fertiliser companies were also producing major agricultural chemicals used in tobacco production. The key informants from the input suppliers cited the following constraints to tobacco inputs production:

1. Shortage of foreign currency

All the four key informants (100\%) from major fertiliser companies in Zimbabwe [ZFC, Windmill, Superfert and Omnia] identified the shortage of foreign currency as the major constraint to inputs production. A key informant from one of the fertiliser companies was quoted saying:

"The major constraint affecting production of chemicals and fertilisers is the shortage of foreign currency. We need foreign currency to import raw materials like ammonium, potash and chemical ingredients and the current allocations we get from the Reserve Bank of Zimbabwe are insufficient. Our machines are currently operating below $30 \%$ capacity due to foreign currency shortages. If we get 100\% support in terms of foreign currency, we can perform at full capacity".

The responses from the key informants were consistent with assertions made by the representatives of Zimbabwe's Industry and Commerce who posited that:

"The continued shortage of foreign currency is making it difficult for industries to import raw materials for use in their production processes, hampering the growth of manufacturing in Zimbabwe", (The Herald, 18 April 2018).

2. High transport costs

The key informants from the fertiliser making companies cited high transport costs as the second major challenge affecting inputs production. A key informant from ZFC was quoted saying

"High transport costs are the second major challenge affecting production of fertiliser. We used to rely on rail transport to carry bulk consignments of fertilisers but at the moment we now use road transport because the rail system is not working properly".

The higher transport costs could also have been exacerbated by high fuel prices. A survey conducted by the researchers at local service stations found that fuel price was averaging \$1.26 (R16.38) per litre of diesel against regional prices of \$US1 (R13) per litre.

\subsubsection{Tobacco Production Stage}

The tobacco farmers were classified as communal, A1 or A2 farmers depending on the land tenure. In Zimbabwe, the smallholder farmers comprised of the A1 and communal farmers. As at the 2017 cropping season, all the 8 districts in Mashonaland Province had a total of 23459 smallholder farmers with Mount Darwin alone having 6688 (TIMB, 2018). The tobacco production process included land preparation [ploughing, disking, ridging and holing out], nursery management, fumigation, fertilizer application, transplanting, weeding and harvesting. The following subsections outline the challenges faced by smallholder farmers in the production and marketing of the tobacco crop.

\subsubsection{Constraints to tobacco production by smallholder tobacco farmers in Mount Darwin District of Zimbabwe.}

The farmer groups were asked to rank the production challenges using the Pairwise ranking matrix. The following section explains how the Pairwise Rank Matrix was used in the study.

\subsubsection{Discussion on the results from the Pairwise Rank Matrix}

The Pairwise ranking matrix is a systematic way to compare various outcomes by comparing the outcomes in pairs (Gay et al., 2016). The approach enhances utilization of qualitative prioritization systems that yields numerical values that can be compared and ranked (Harder, 2013). In this study, the responses from individual smallholder farmers [collected through questionnaires] and from group leaders [through focus group discussions] were used to identify the institutional and socio-economic constraints to tobacco production. The production constraints were identified and recorded in a matrix table as shown in Table 2 below. The farmer groups were asked to compare each constraint to the other constraints individually. The number of times each constraint was chosen was summed. The constraint with the largest score/sum was deemed to be the major one and was ranked 1 . The constraint with the second largest score was ranked 2 and the rest followed that systematic order. The study showed an array of institutional and socio economic constraints to smallholder tobacco production. The results from the matrix ranking were as follows: dry spells (1), shortage of labour (2), high cost of inputs (3), shortage of curing fuel (4), pests and diseases (5), shortage of barns (5), shortage of draft power (7), lack of finance (8), lack of production knowledge (9) and lack of access to insurance services (10). The detailed sores are shown on the Pairwise Rank Matrix (Table 2) below. 
The following subsections discusses the findings from the Pairwise rank matrix (Table2) in detail.

1. Dry Spells and unpredictable rainfall patterns.

Results from the study ranked dry spells and unpredictable weather patterns as the major constraint to tobacco production. The findings concurred with (Makuvaro et al., 2017) who posited that high rainfall variability was a major constraint affecting smallholder farmers in Zimbabwe. An example is the 2016/17 season and the 2017/18 cropping seasons where different rainfall patterns were recorded. A key informant from Mount Darwin Meteorological services was quoted saying "The rainfall pattern varies from year to year. Last season we received an average of $1100 \mathrm{~mm}$ per annum and the rainfall was fairly distributed. This season [2017-18] we only received $750 \mathrm{~mm}$ and the distribution pattern was very poor"

Table 2. The results of the Pairwise Rank Matrix showing major tobacco production constraints in Mount Darwin District.

\begin{tabular}{|c|c|c|c|c|c|c|c|c|c|c|c|c|}
\hline Major Constra & $\begin{array}{l}\text { 1. Shortage of } \\
\text { labour }\end{array}$ & $\begin{array}{l}\text { 2. shortage } \\
\text { of barns }\end{array}$ & $\begin{array}{l}\text { 3. pests and } \\
\text { diseases }\end{array}$ & 4. Dry Spells & $\begin{array}{l}5 . \text { lack of } \\
\text { finance }\end{array}$ & \begin{tabular}{|l|} 
6. high \\
costs of \\
inputs
\end{tabular} & $\begin{array}{l}\text { 7. shortage } \\
\text { of fuel for } \\
\text { curing } \\
\text { tobacco }\end{array}$ & $\begin{array}{l}\text { 8. shortage } \\
\text { of draft } \\
\text { power }\end{array}$ & $\begin{array}{l}\text { 9. lack of } \\
\text { production } \\
\text { knowledge }\end{array}$ & $\begin{array}{l}10 \text { lack of } \\
\text { access to } \\
\text { insurance } \\
\text { services }\end{array}$ & Score & Rank \\
\hline \begin{tabular}{|l|} 
1. Shortage \\
of labour
\end{tabular} & & 1 & 1 & 4 & 1 & 1 & 1 & 1 & 1 & 1 & 8 & 2 \\
\hline \begin{tabular}{|l|}
$\begin{array}{l}\text { 2. shortage } \\
\text { of barns }\end{array}$ \\
\end{tabular} & & & & 4 & & 6 & 7 & 2 & 2 & & 4 & 5 \\
\hline \begin{tabular}{|l|}
$\begin{array}{l}\text { 3. pests and } \\
\text { diseases }\end{array}$ \\
\end{tabular} & & & & 4 & 3 & 6 & 7 & 3 & 3 & & 4 & 5 \\
\hline 4. Dry Spells & & & & & 4 & 4 & 4 & 4 & 4 & 4 & 9 & 1 \\
\hline \begin{tabular}{|l|}
$\begin{array}{l}5 . \text { lack of } \\
\text { finance }\end{array}$ \\
\end{tabular} & & & & & & 6 & 7 & 8 & & 10 & 2 & 8 \\
\hline \begin{tabular}{|l|}
$\begin{array}{l}\text { 6. high costs } \\
\text { of inputs }\end{array}$ \\
\end{tabular} & & & & & & & 6 & 6 & 6 & 6 & 7 & 3 \\
\hline $\begin{array}{l}\text { 7. shortage } \\
\text { curing fuel }\end{array}$ & & & & & & & & 7 & 7 & 7 & 6 & 4 \\
\hline \begin{tabular}{|l|}
$\begin{array}{l}\text { 8. shortage } \\
\text { of draft } \\
\text { power }\end{array}$ \\
\end{tabular} & & & & & & & & & 8 & 10 & 2 & 7 \\
\hline \begin{tabular}{|l|} 
9. lack of \\
production \\
knowledge \\
\end{tabular} & & & & & & & & & & 9 & 1 & 9 \\
\hline $\begin{array}{l}10 \text { lack of } \\
\text { access to } \\
\text { insurance } \\
\text { services }\end{array}$ & & & & & & & & & & & 0 & 10 \\
\hline
\end{tabular}

Source: Survey data (2018)

\section{Shortage of labour}

Shortage of labour was ranked the second major constraint to tobacco production as shown on Table 2 above. Tobacco is a labour intensive crop and the farmers revealed that they supplement family labour with hired labour. The findings supports the assertions by Scoones et al., (2016) which revealed that tobacco operations were highly labour intensive, non-mechanized, and highly dependent on hired workforce. The modes of payments for labour were as shown on Figure 2 below

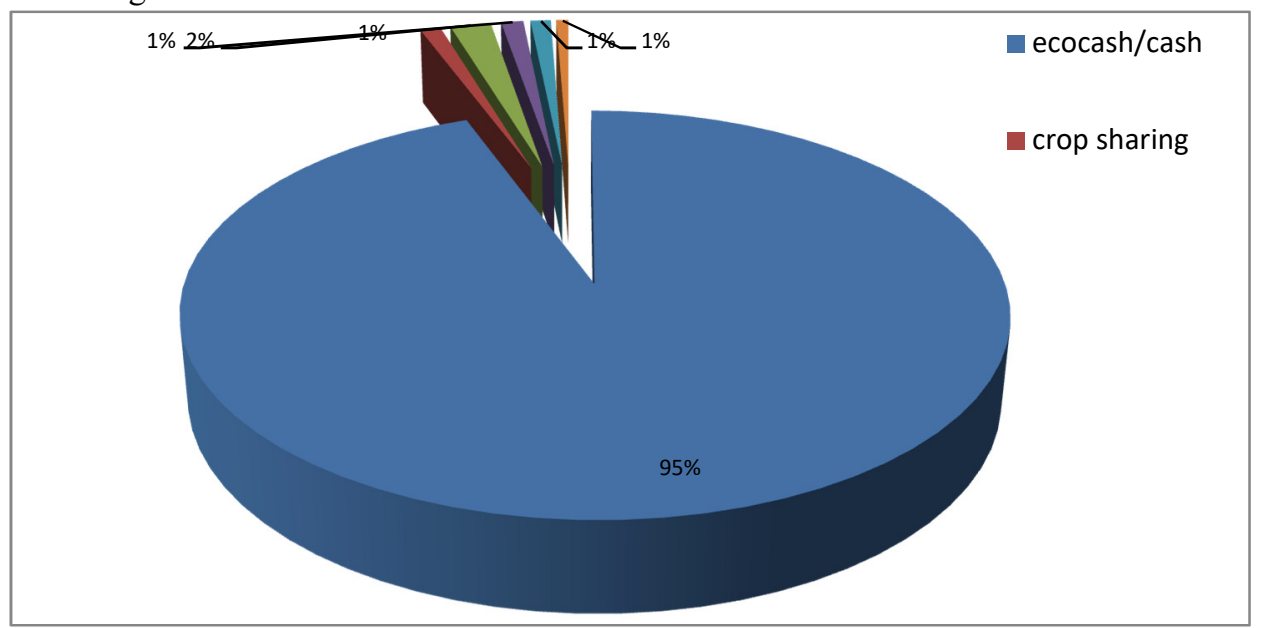

Figure 2: Methods of paying labour by smallholder farmers in Mount Darwin Source: Authors' fieldwork, 2018 
Findings from the 380 interviewed farmers revealed that the smallholder farmers paid their labour in different forms. Cash and eco-cash [mobile money transfer] was the most common payment method (95\%), crop sharing $(1 \%)$, groceries $(2 \%)$, agricultural inputs $(1 \%)$, leasing land $(1 \%)$ and leasing cattle (1\%). Figure 2 above shows the different forms of paying labour and the corresponding percentages.

The study revealed that smallholder tobacco farmers pay for labour at different time intervals. The summary for the payment time frames is as shown on the Figure 3 below.

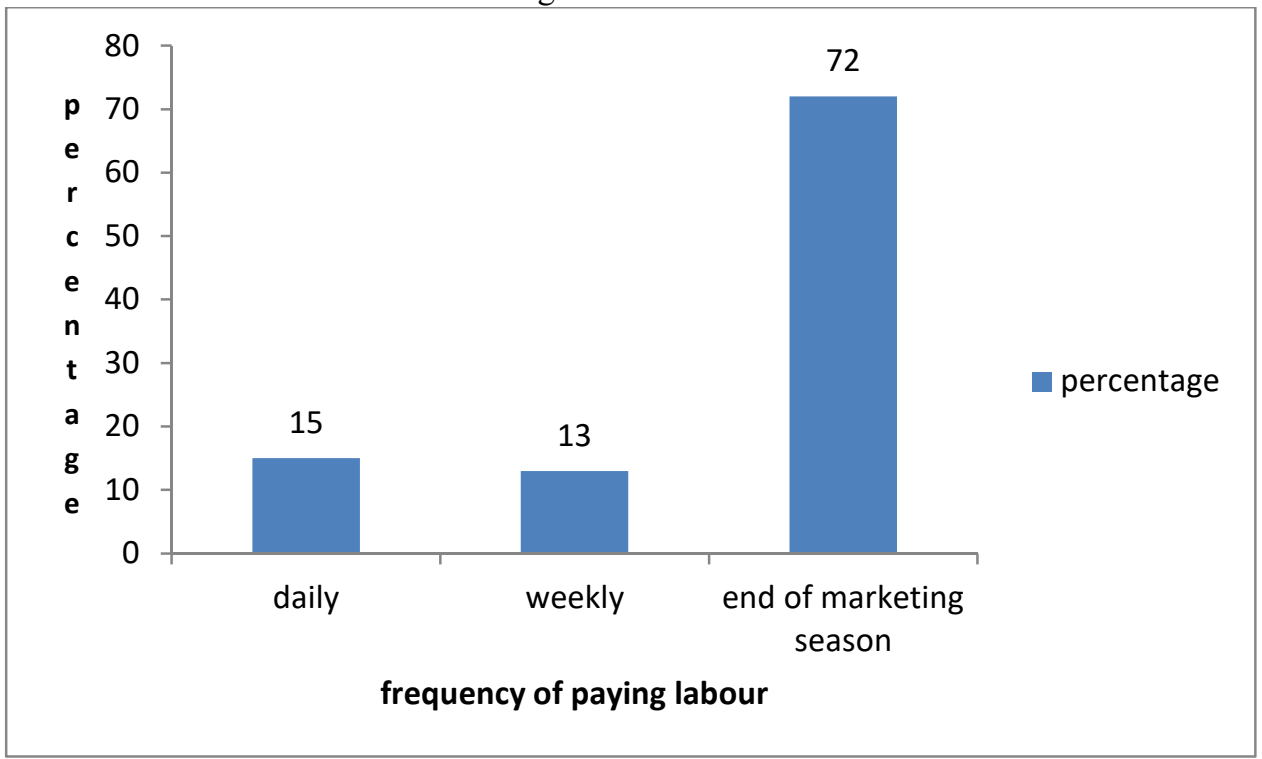

Figure 3: Frequency for paying labour

Source: Authors' fieldwork, 2018

Seventy two per-cent $(72 \%)$ of the interviewed farmers revealed that they pay their labour at the end of the marketing season whilst $15 \%$ pay casual labour on daily basis. Thirteen per-cent of the farmers pay their labour weekly.

\section{High costs of agricultural inputs}

High cost of inputs was ranked the third constraint to smallholder tobacco production. The research findings concur with Mutambara, (2016) who revealed that smallholder farmers faced challenges in accessing agricultural inputs because they were expensive. A survey conducted during the 2018 tobacco marketing season, showed that a simple hectare package of inputs was valued at $\$ 889.95$ as shown in table 2 below.

Table 3: Cost of tobacco inputs per hectare

\begin{tabular}{|c|c|c|c|c|c|c|}
\hline Input & $\begin{array}{ll}\text { Unit } & \text { of } \\
\text { measurement }\end{array}$ & $\begin{array}{l}\text { Unit } \\
\text { (US\$) }\end{array}$ & cost & $\begin{array}{l}\text { Total quantity required per } \\
\text { ha }\end{array}$ & $\begin{array}{l}\text { Total } \\
\text { (US\$) }\end{array}$ & Cost \\
\hline$\overline{\text { Seed }}$ & $25 \mathrm{~g}$ & $\$ 25$ & & 1 & 25 & \\
\hline Compound S & $50 \mathrm{~kg}$ & 37 & & 10 & 370 & \\
\hline Ammonium Nitrate & $50 \mathrm{~kg}$ & 34 & & 5 & 170 & \\
\hline Decanol & Litres & 15.45 & & 1 & 15.45 & \\
\hline Thunder & $500 \mathrm{mls}$ & 38 & & 1 & 38 & \\
\hline Copper Oxychloride & $200 \mathrm{~g}$ & 2.90 & & 1 & 2.90 & \\
\hline Mancozeb & $1 \mathrm{~kg}$ & 13.15 & & 1 & 13.15 & \\
\hline Command/Chlomazone & Llitre & 13 & & 1 & 13 & \\
\hline Shavit & 1litre & 27 & & 1 & 27 & \\
\hline Lambda & $500 \mathrm{mls}$ & 6.85 & & 1 & 6.85 & \\
\hline Imindachloprid 200SL & 1litre & 15.80 & & 1 & 15.80 & \\
\hline Fusilade Super & 1litre & 28 & & 1 & 28 & \\
\hline Authority & 1litre & 90 & & 1 & 90 & \\
\hline Bion & $60 \mathrm{~g}$ & 45.80 & & 1 & 48.8 & \\
\hline Nemacure & 1litre & 26 & & 1 & 26 & \\
\hline Total & & & & & 889.95 & \\
\hline
\end{tabular}

Source: Compilations from Input suppliers; July 2018

$$
\text { 4. Depleting firewood sources }
$$

Eighty four percent of the interviewed farmers indicated that they use wood fuel to cure tobacco. Fifteen percent used both firewood and coal with the remaining relying on coal as a source of fuel. The farmers cited the depleting 
sources of firewood as one of the major constraint that affected tobacco production. Statistics showing the fuel types used by farmers to cure tobacco in Mt Darwin is as shown in Figure 4 below.

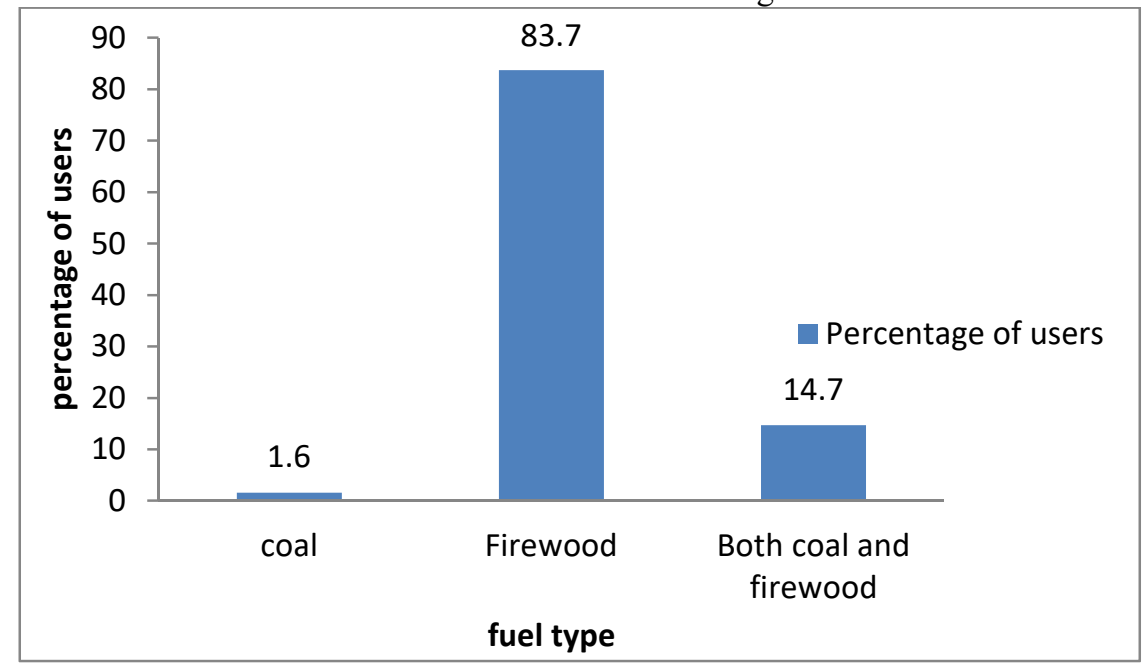

Figure 4: Type of fuel used to cure tobacco and percentage of users.

Source: Authors fieldwork, 2018

Demand for wood fuel was rising exponentially due to increasing number of farmers growing tobacco. However the rate of reforestation was lower than the rate at which the farmers were cutting down trees. This finding was supported by The Forestry Commission which further revealed that "flue-cured tobacco curing contributed 15 percent of the aggregate deforestation rate in Zimbabwe" (Kawadza, 2018). As a result, a serious fire-wood crisis threatened the sustainability of the tobacco value chain in the area. Plate 1 below shows stacks for tobacco curing.

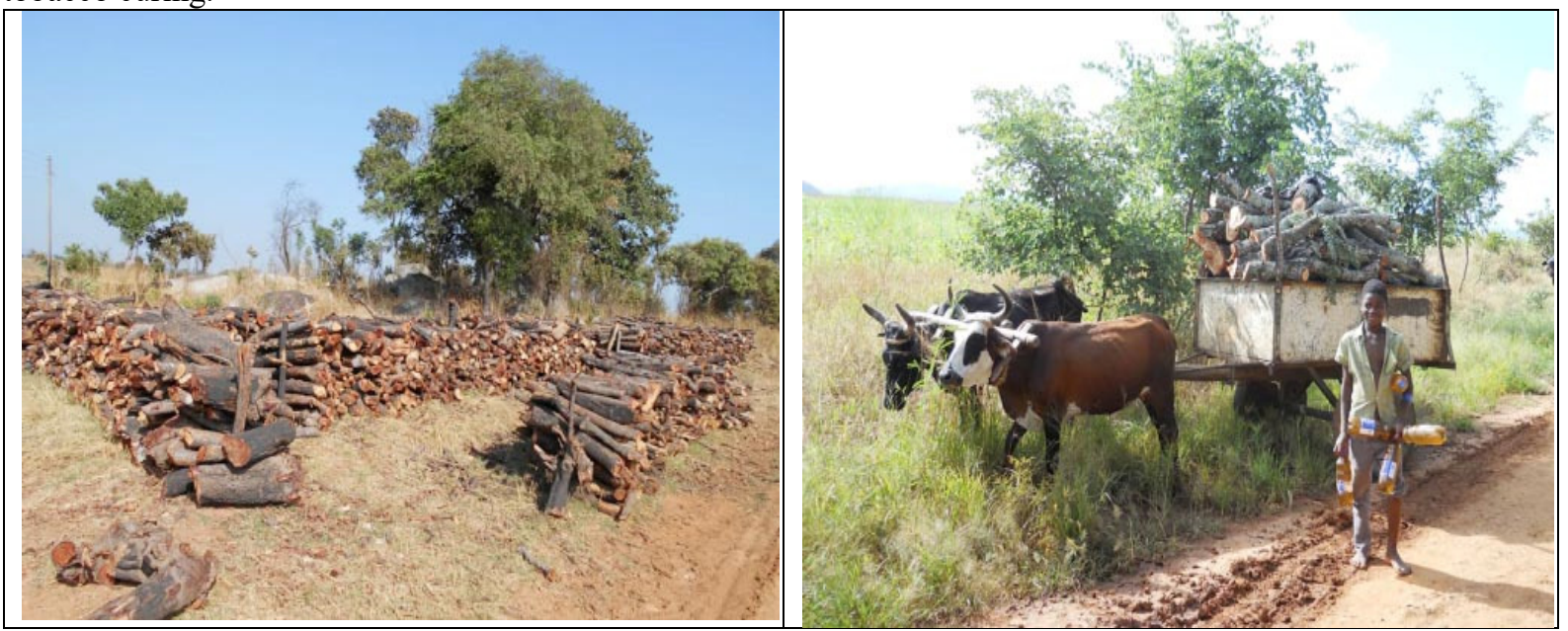

Plate1: Wood stocked up for tobacco curing.

Indigenous wood stocked up for tobacco curing in Zimbabwe (left); Wood being transported for curing tobacco (right).

Source: (Kawadza, 2018)

\section{Crop diseases}

The Pairwise rank matrix Table1 ranked crop diseases the $5^{\text {th }}$ major constraint to smallholder tobacco production. The farmers revealed that there was an outbreak of Potato virus disease in Mt Darwin during the 2017/18 season. The assertion was supported by responses from the TIMB key informant who said "The disease outbreak was mainly due to failure by farmers to stick to regulations relating to destruction of stalks and dead periods (like planting dates) as provided for under the Plant Pests and Diseases Act”. In Zimbabwe all tobacco stalks should be destroyed by the $15^{\text {th }}$ of May every year (GOZ, 2018).

6. Lack of curing facilities

Results shown by the Pairwise matrix highlighted the lack of curing facilities such as barns as the $6^{\text {th }}$ major constraint affecting tobacco production by smallholder farmers. A survey conducted in the farming areas also noted that critical infrastructure like tobacco barns which were inherited from the former White Large Scale Commercial Farmers was dilapidated and needed maintenance and renovations. Figure 6 below shows some 
dilapidated tobacco curing barns in Camperdown resettlement farm in Mount Darwin.

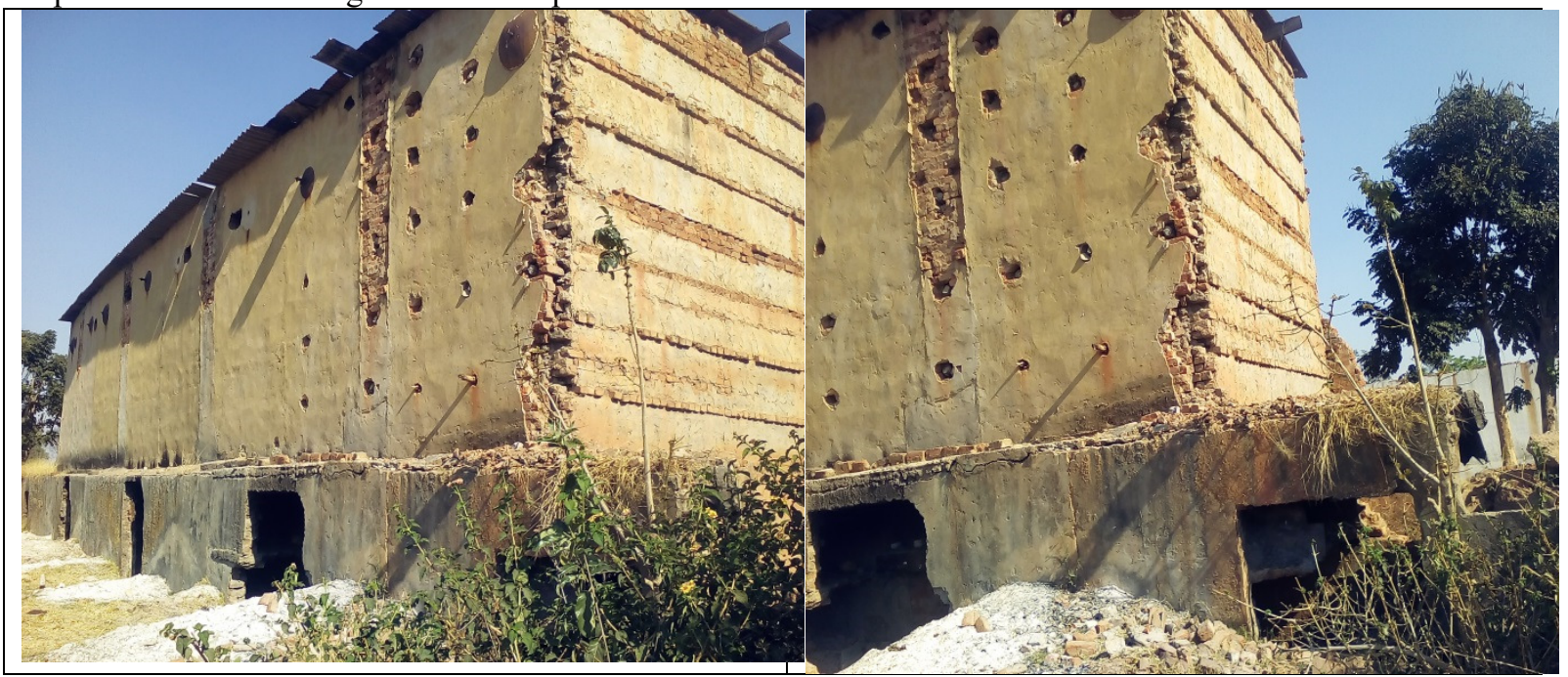

Plate 2: Dilapidated tobacco barns at Camperdown Farm in Mt Darwin.

Source: Authors 2018

7. Shortage of draft power

The research identified lack of draft power as the $7^{\text {th }}$ constraint to tobacco production by smallholder farmers in Mt Darwin. Most households relied on cattle for draft power. The research findings revealed the average cattle ownership per household as 9 herds. It also noted that more than $30 \%$ of the respondents had less than 5 cattle. The interviewed farmers highlighted that the cost of tilling one hectare of land averaged between $\$ 50-\$ 100$ and this cost was considered high.

8. Limited access to agricultural finance

Responses from the smallholder tobacco farmers cited access to agricultural finance as one of the major institutional constraints affecting tobacco production in Zimbabwe. Paradoxically, it was the smallholder farmers who produced more than $80 \%$ of the country's tobacco (TIMB, 2018). Research findings indicated that besides accessing agricultural finance from contractors, very few farmers got supplementary funding from banks (5\%), micro-finance institutions $(2 \%)$ and government $(3 \%)$. However, $90 \%$ of the respondents indicated that they do not have access to alternative agricultural finance other than from tobacco contractors. Figure 5 below gives a detailed statistics on farmers' alternative sources of finance.

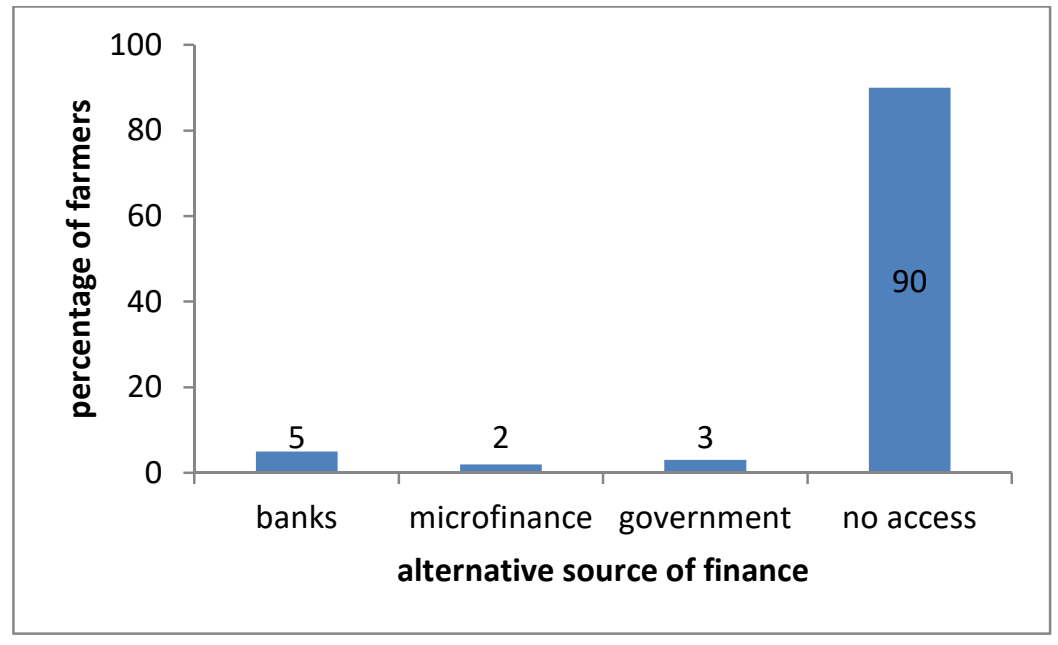

Figure 5: Alternative sources of finance for smallholder farmers and percentage of farmers accessing the funds Source: Authors' fieldwork 2018

The research findings supports the assertions by Mukwereza (2013), who revealed most institutions prefer to support large scale farmers and side-line smallholder farmers. The factors that led to financial exclusion of smallholder farmers included high interest rates (15\% per annum), lack of collateral and insecurity of tenure.

The key informants from Agribank, CBZ Bank and ZB Bank were interviewed on smallholder access to affordable agricultural loans. All the respondents revealed that funding smallholder tobacco farmers was considered to be risky due to lack of collateral. An informant from one of the banks was quoted saying "The bank requires collateral in form of immovable assets such as houses with title deeds. Unfortunately most smallholder 
farmers do not have these documents and this makes them excluded from accessing agricultural loans". This research finding is in supports of assertions by Mutambara (2016) who revealed that the smallholder farmers needed to satisfy a long list of bank requirements including collateral security for them to qualify for bank loans. The smallholder farmers could not use land as security because the farmers did not have title over land.

The key informants from the country's agricultural bank said "The bank mobilised \$105 million for the 20182019 cropping season. However the facility is targeted at farmers on the basis of collateral and 99-year leases." Unfortunately the 99 year leases were only available to some A2 farmers thereby making it difficult for the smallholder communal and A1 farmers to access the loan.

The banks also revealed that they were discouraged to provide agricultural loans to smallholder farmers because some farmers could not pay back the loans. They cited political interference especially in the A1 farmers as a major drawback to loan recoveries among the smallholder farmers. There was a general perception among the farmers that the loaned funds were donations from the government thereby leading to bad debts.

\section{Agronomic and marketing knowledge gap}

Interviews with smallholder farmers and extension staff cited lack of agronomic knowledge on tobacco production as one of the factors attributing to low productivity and low commodity quality. The extension staff attributed the knowledge gap to lack of experience because the tobacco crop was relatively new to some smallholder farmers. Tobacco was perceived to be a crop of the elite given that it used to be grown by the white large scale commercial farmers.

\section{Limited access to insurance services}

Lack of access to insurance services against vagaries of nature such as hail and fire was ranked the $10^{\text {th }}$ major constraint to tobacco production in Mt Darwin. Crop losses through hail have been very rampant (Guta, 2017; Kadungure, 2017). Sixty percent of the tobacco contractors and merchants revealed that they were not forcing farmers to insure their crops despite the fact that most farmers kept on losing their crop to hail and other vagaries of nature. According to the survey conducted, only the TIMB and Shasha Tobacco made it mandatory for their contracted farmers to be insured. Although the farmers identified hail and theft in transit as some of the challenges they faced, some viewed investing in insurance as an unnecessary expense. Their argument was based on their previous experiences with insurance companies when the farmers lost their investments during the transformative stages of the dollarization of the Zimbabwean economy in 2009. During the dollarization period all the investments that had been saved in banks and insurance policies were lost. The development could have resulted in farmers lacking confidence in the insurance sector.

\section{Tobacco Marketing}

As at the time of the study, Zimbabwe tobacco value chain had a dual marketing system consisting of the traditional auctioning arrangement and the contract marketing arrangement. As at end of the 2017 marketing season, the auction marketing arrangement accounted for close to $20 \%$ of total tobacco sales whilst the contract arrangement accounted for $80 \%$ (TIMB, 2018).

If the farmer had own resources to finance production, the auction system would be the appropriate marketing channel to use. Conversely if the farmer decided to be pre-financed by any of the licenced contractors, s/he would be obliged to sell the contracted crop to the contractor using the contract marketing arrangement. The following section gives an outline of the auction marketing arrangement.

a. Auction marketing arrangement

Under the auction marketing arrangement, non-contracted farmers delivered their tobacco crop to auction floors where the crop was traded. Some buyers sold the crop to merchants who in-turn processed the commodity before it got to consumers through distributors. Some merchants directly bought the crop at auction floors by-passing the buyers. The tobacco flow-map under auction arrangement was as shown in Figure 6 below:

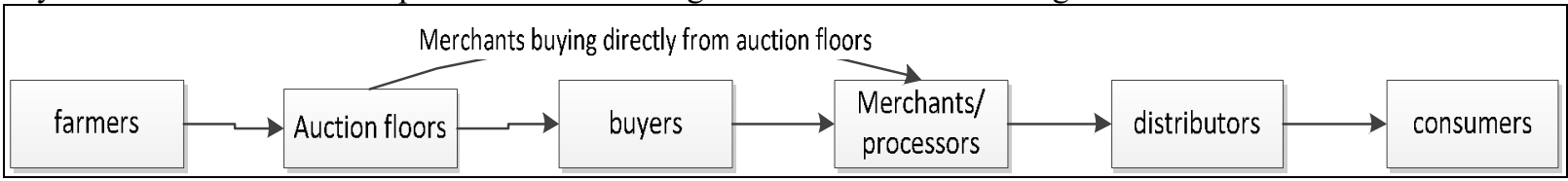

Figure 6: Tobacco flow map under auction marketing institutional arrangements

Source: Authors 2018

In 2018, when the study was conducted, all the non-contracted tobacco was sold under the auction arrangement. All the non-contracted tobacco farmers from the different parts of the country delivered their tobacco crop to public auctions situated in Harare. The buyers from across the globe converged and traded with the farmers at the auction floors. During the period of the study, the tobacco marketing under auction arrangement was conducted at three privately owned auction floors namely Tobacco Sales Floor (TSF) commanding 64\% market share, Boka Tobacco Floor (BTF) with $18 \%$ and Premier Tobacco Floor 18\%. The tobacco volumes and value sold under auction during the 2017 season were as shown by Figure 7 below: 


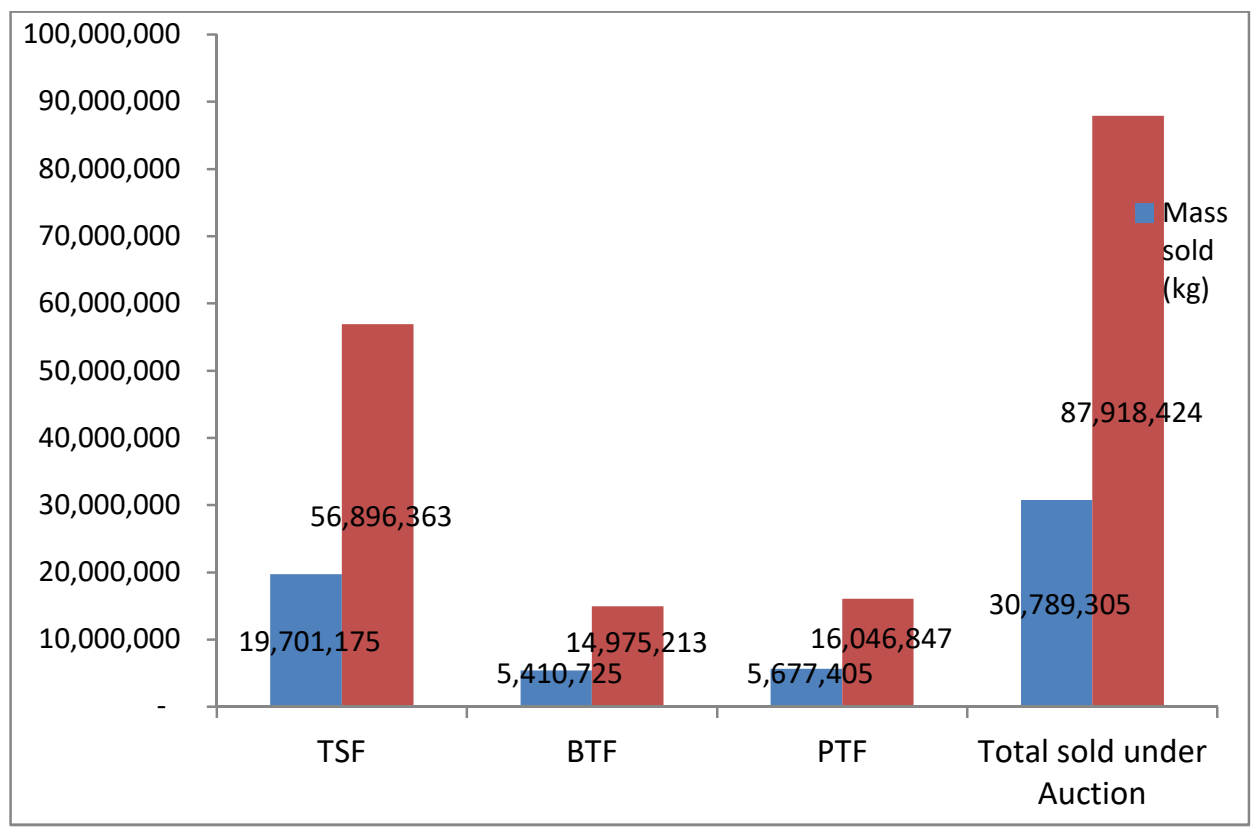

Figure 7: Tobacco sales figures under auction institutional arrangement for the 2017 marketing season.

Source: (ZFU, 2017)

The next subsections outline the constraints affecting tobacco marketing by smallholder farmers. The major marketing challenges were outlined by the farmers. The major constraints to marketing were ranked using the Pairwise matrix and the major challenge was ranked 1. The Pairwise comparisons method was used based on the psychological observation that the human brain cannot compare more than 5 independent values in one moment [so called cognitive overload], (Ramík, 2017). The responses were as follows: cash shortages (ranked 1), low producer price (ranked 2), poor services (ranked 3), high transport costs (ranked 4), long waiting periods (ranked 5), theft in transit (ranked 6) and exploitation by middlemen (ranked 7), The detailed research findings were as shown in Table 4 below:

Table 4: Pairwise ranking matrix for major marketing constraints affecting smallholder tobacco farmers.

\begin{tabular}{|c|c|c|c|c|c|c|c|c|c|}
\hline & \multicolumn{7}{|c|}{ Constraint number } & & \\
\hline Constraint & 1 & 2 & 3 & 4 & 5 & 6 & 7 & Score & Rank \\
\hline 1. theft in transit & & 2 & 3 & 4 & 4 & 1 & 7 & 1 & 6 \\
\hline $\begin{array}{l}\text { 2. Low producer } \\
\text { prices }\end{array}$ & & & 2 & 2 & 2 & 2 & 7 & 5 & 2 \\
\hline $\begin{array}{l}\text { 3. High transport } \\
\text { costs }\end{array}$ & & & & 4 & 3 & 3 & 7 & 3 & 4 \\
\hline 4. poor services & & & & & 5 & 4 & 7 & 4 & 3 \\
\hline $\begin{array}{l}\text { 5. long waiting } \\
\text { periods }\end{array}$ & & & & & & 5 & 7 & 2 & 5 \\
\hline $\begin{array}{l}\text { 6. exploitation by } \\
\text { middlemen }\end{array}$ & & & & & & & 7 & 0 & 7 \\
\hline 7. cash shortages & & & & & & & & 6 & 1 \\
\hline
\end{tabular}

Source: Authors' fieldwork, 2018

The section below gives the detailed discussion of the marketing constraints outlined on Table 3 above.

$$
\text { i. } \quad \text { Shortage of cash }
$$

The results from the Pairwise ranking cited shortage of cash as the major marketing challenge affecting tobacco farmers. One farmer from Mutungagore area of Mt Darwin was quoted saying "I was only paid $\$ 300$ cash and the balance was deposited into my bank account. There is no cash at the bank. I need cash to pay for transport and labour. I do not understand why we cannot access cash yet money changers are selling us cash just outside the tobacco floors".

The farmers revealed that they desperately needed cash to pay for the labourers who assisted them in planting, weeding, de-sucking, reaping, grading and baling. A survey conducted at the local banks in Mt Darwin and Bindura Town found that banks were limiting cash withdrawals to $\$ 10$ per day. Farmers were paid through bank transfers 
with options of mobile money transfers (eco-cash/one-wallet). Points of sale [swiping] machines were not readily available in all the parts of rural areas where tobacco is the major crop. Network connectivity was also a challenge making it difficult for farmers to trade using plastic money. A survey conducted the tobacco floors identified some cash barons taking advantage of the cash desperate farmers. The farmers were requested to transfer $\$ 100$ into a cash baron's account to be given $\$ 70$ cash.

ii Low Producer Prices

The research identified low producer prices as the second major constraint to tobacco marketing. According to the responses from the Mt Darwin farmers, the highest price paid under auction was $\$ 4.99$ per and the lowest price of $\$ 1$ per kg. The study average price was $\$ 2.82$ which the farmers felt to be low given the high production costs.

iii. Poor services.

Poor services at tobacco floors were ranked the 3rd major constraint to tobacco marketing. The farmers revealed that the auction floors were crowded during the marketing season. The standards of hygiene were low. Some farmers spend up to seven days at tobacco floors without proper accommodation and other amenities.

iv High Transport costs

The respondents indicated the high transport costs to ferry tobacco to the distant floors located in Harare and Mvurwi was the $4^{\text {th }}$ major marketing constraint they face. The study revealed that $19.5 \%$ of the farmers were located $5 \mathrm{~km}$ away from tarred roads, $46.3 \%$ situated in areas $10-20 \mathrm{~km}$ away from the major tarred road and 34.2 located on distances more than $20 \mathrm{~km}$ away from the tarred road. The farmers were paying $\$ 10-\$ 15$ per bale for distances ranging between $100-150 \mathrm{~km}$. Table 4 below shows the number of farmers and the corresponding distances from the tarred road.

Table 5: The number of farmers and the distances from the main tarred road

\begin{tabular}{ll}
\hline Distance & Number of farmers \\
\hline$<\mathbf{5 k m}$ & 74 \\
$\mathbf{1 0 - 2 0} \mathbf{k m}$ & 176 \\
$>\mathbf{2 0} \mathbf{k m}$ & 130 \\
\hline Total & 380 \\
\hline \multicolumn{1}{c}{ Long waiting periods }
\end{tabular}

The research findings identified long waiting periods as the $5^{\text {th }}$ constraint to tobacco marketing. The findings from the research revealed that $14.2 \%$ of the farmers interviewed spend 1 day at the floors, $37.4 \%$ served within 2 days, and $23.2 \%$ within 3 . The detailed statistics on the number of days the farmers spend at the floors are as shown in Figure 8 below.

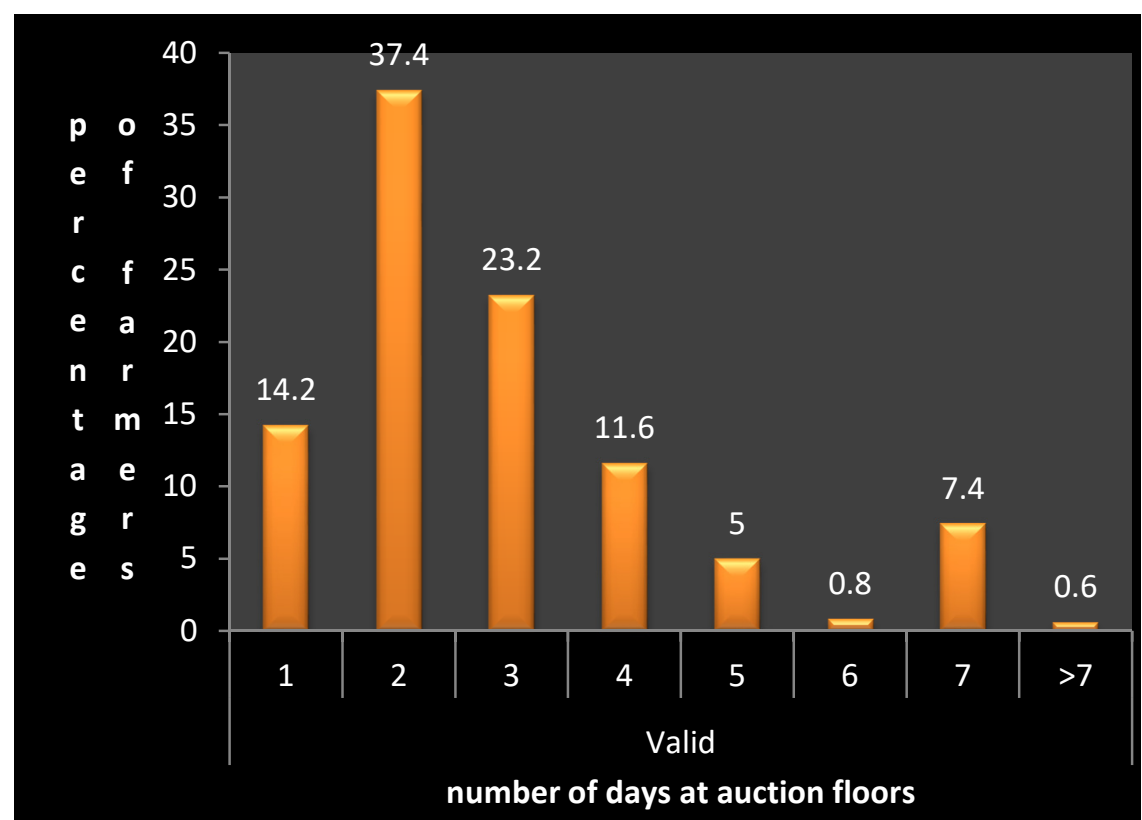

Figure 8: Number of days spend by the farmers at tobacco floors Source: Authors' field work (2018)

\section{Theft in transit}

The $6^{\text {th }}$ major constraint to tobacco marketing was theft of bales in transit. The tobacco farmers were easily targetted by thieves who stole the tobacco bales in transit. Some farmers also lost substantial amounts of cash to thieves at the auction floors. The Zimbabwe Republic Police reported that there was an increase in theft of tobacco bales being transported to auction floors. The thieves were reported to be targeting farmers at night as they queue 
with loaded trucks outside the auction floors. The thieves used sharp knives and machetes to cut ropes and tents and load bales from trucks.

6. Exploitation by buyers and middlemen.

The research findings revealed that $7.9 \%$ of the interviewed farmers felt shortchanged when they sell their produce to buyers and middlemen. Some farmers ended up selling their tobacco to unlicenced midlemen for various reasons such as lack of valid grower numbers, lack of valid bank accounts, inconviniences caused by traveling to Harare and need for hard cash which the middlemen had. Due to the stated institutional and socio-economic constraints, the affected farmers were likely to lose the $12.5 \%$ export incentive given to tobacco growers by the Reserve Bank of Zimbabwe (RBZ). Under the RBZ export incentive, the payment was made to the tobacco farmers who could have sold their tobacco through the normal marketing channels and not through middlemen. The incentive was paid directly into the farmer's bank account which made it impossible for unregistered farmers to access. The following section looked at the marketing function along the tobacco value chain.

The constraints facing tobacco production and marketing in the area are summarised as:

i. $\quad$ Declining sales volumes

According to the key informants from the auction floors, the main challenge that affected the auction floors was the declining tobacco volumes sold through the auction arrangement. The concern was supported by reports from the TIMB which revealed that auction floors accounted for close to $20 \%$ of the total tobacco sold during the 2017 marketing season (TIMB, 2018). Given that the auction arrangement used to account for $100 \%$ of the country's tobacco marketing channel, it was evident that the survival of Zimbabwe's auction marketing arrangement was under serious threat. Figure 9 shows the declining volume trends sold under auction marketing arrangement between 2012 and 2017:

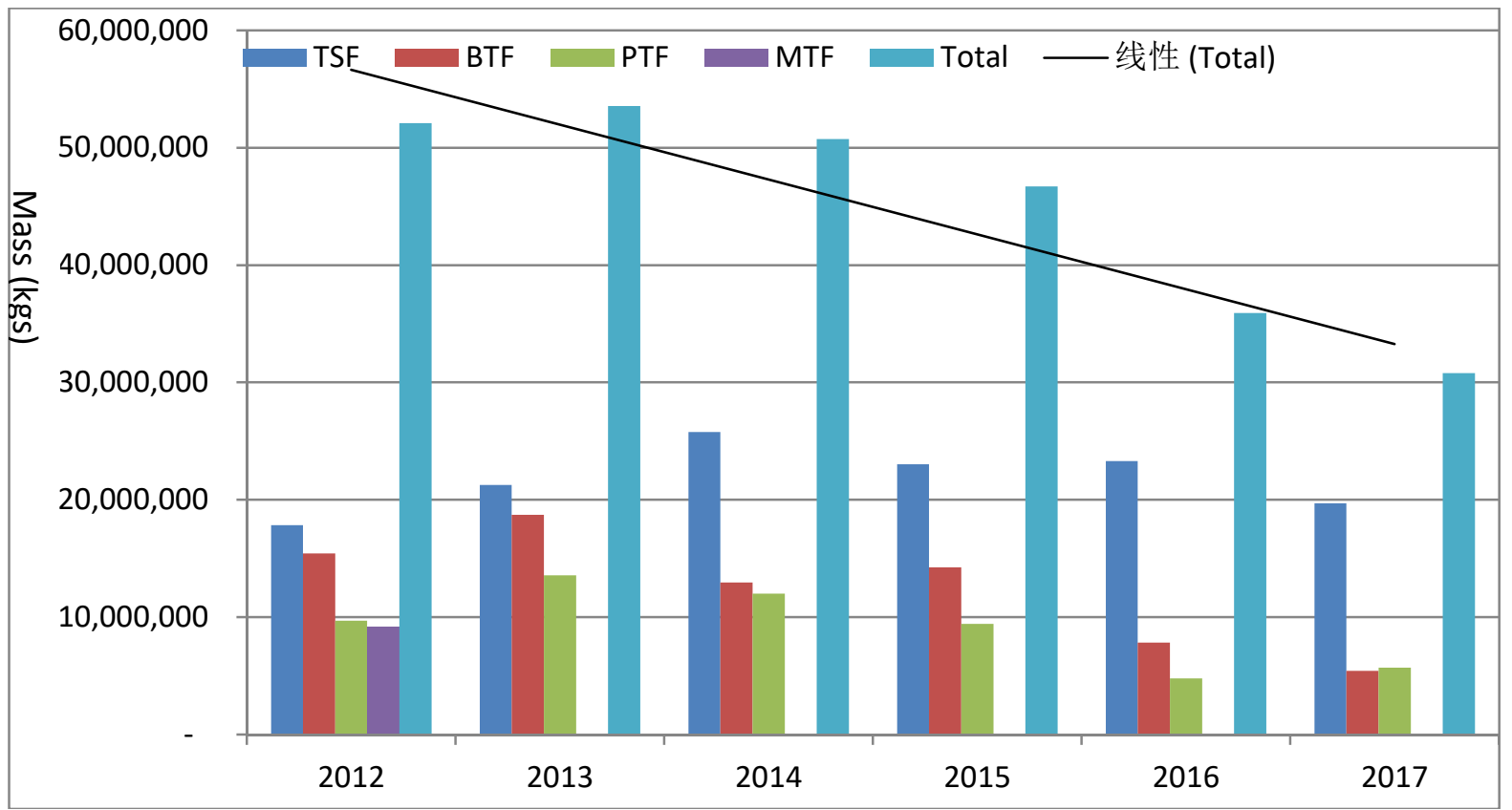

Figure 9:Trend of tobacco sales volumes through auction floors (2012-2017)

Source: TIMB, 2017

The responses from the farmers revealed that they felt that the synergies created between the auction floors and the buyers were a deliberate ploy by the private players to connive and hoodwink them through paying low tobacco prices. The farmers were arguing that if the prices paid at auctions were the best prices offered then the private buyers would not find it viable to buy tobacco at auction floors for re-sale to big merchants. The farmers attributed the declining volumes traded through auction arrangement to unfavourable producer prices paid at the auction floors. The producers revealed that for the past six years, tobacco prices under auction have never exceeded $\$ 4.99 / \mathrm{kg}$ (R64.87/ kg) despite the good quality of tobacco. That was unlike on the contract market where good quality tobacco could go for as high as $\$ 6$ per $\mathrm{kg}(\mathrm{R} 78 / \mathrm{kg})$. During the 2017 marketing season, the highest and lowest prices were as shown in Figure 10 below: 


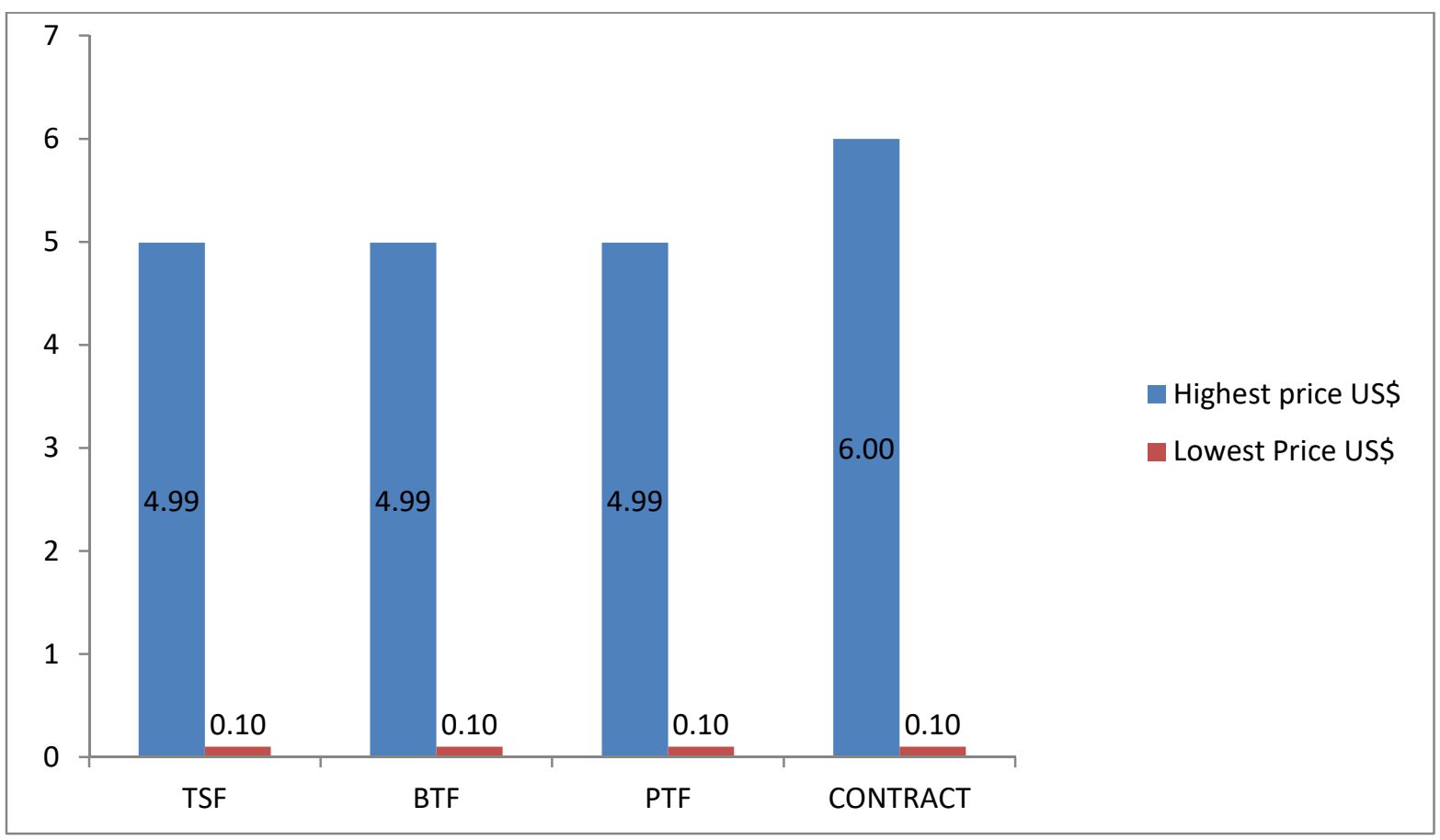

Figure 10: tobacco prices for the 2017 marketing season Source: (ZFU, 2017)

ii. $\quad$ Failure by the farmers to register as tobacco producers.

Among other institutional constraints raised by the auction floors were instances of farmers coming to market their tobacco without grower numbers. According to the regulations from the TIMB, all tobacco growers were supposed to register with the board at the onset of each cropping season. However, responses from the contractors revealed that a number of farmers produced tobacco without meeting this requirement only to be discovered during the marketing season. That resulted in delays when the farmers register in retrospect. Late registration attracted a fine of US\$150 (R1950) against US\$10 (R130) normal registration fee. The fine was considered high leading to some farmers resorting to selling their tobacco to unregistered middlemen instead of the formal marketing arrangements. The following sections examine the contract marketing arrangement.

The contract marketing arrangement

Under the contract marketing arrangement, the farmers delivered their crop to contract floors where the inputs advanced to farmers were deducted. The contractors either sell the commodity to merchants or process the tobacco before it is sold to consumers through distributors. The commodity flow map was as illustrated on Fig 11 below

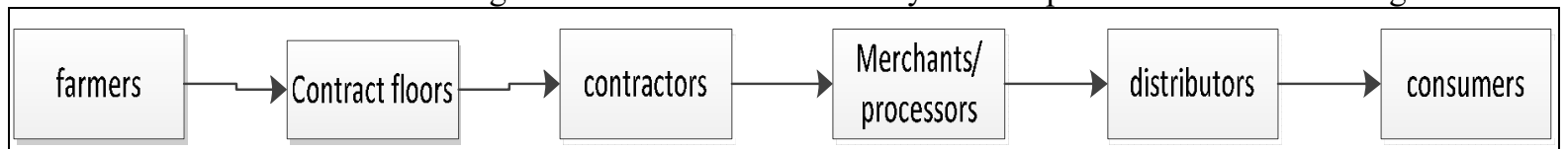

Figure 11: Tobacco flow map under contract marketing arrangement

Source: Authors (2018)

All the tobacco contractors had their contract floors located in Harare. However, contractors like MTC had decentralised their operations by setting up contract floors in tobacco production areas of Mvurwi, Karoi and Rusape which are away from Harare.

Table 6: Reasons for participating in contract farming arrangements

\begin{tabular}{lll}
\hline Reason for participating in contract & Frequency & Percentage \\
\hline access to inputs & 101 & 32.4 \\
access to better prices & 97 & 31.1 \\
access to better services & 50 & 16.04 \\
access to extension services & 34 & 10.9 \\
Access to inputs in time & 22 & 7 \\
Access to cheaper transport & 3 & 0.96 \\
Access to packaging materials & 5 & 1.6 \\
\hline Total & 312 & 100 \\
\hline
\end{tabular}

The responses from 312 farmers producing tobacco under contract cited access to inputs (32.4\%), access to better prices $(31.1 \%)$, availability of better services $(16.04 \%)$, access to extension services $(10.9 \%)$, timely 
provision of inputs $(7 \%)$, access to cheaper transport $(0.96 \%)$ and access to packaging material $(1.6 \%)$ as some of the reasons they prefer to produce under contract. Detailed statistics on the reasons why the farmers prefer to produce under contract is as shown in Table 6 above.

Twenty five per-cent of the interviewed farmers revealed that they preferred to deliver under contract floors because contract prices were better than auction prices. The argument was substantiated by the price trends in Figure 12 below. As shown by Figure 12, contract prices have been higher than auction prices since the 2008 tobacco marketing season.

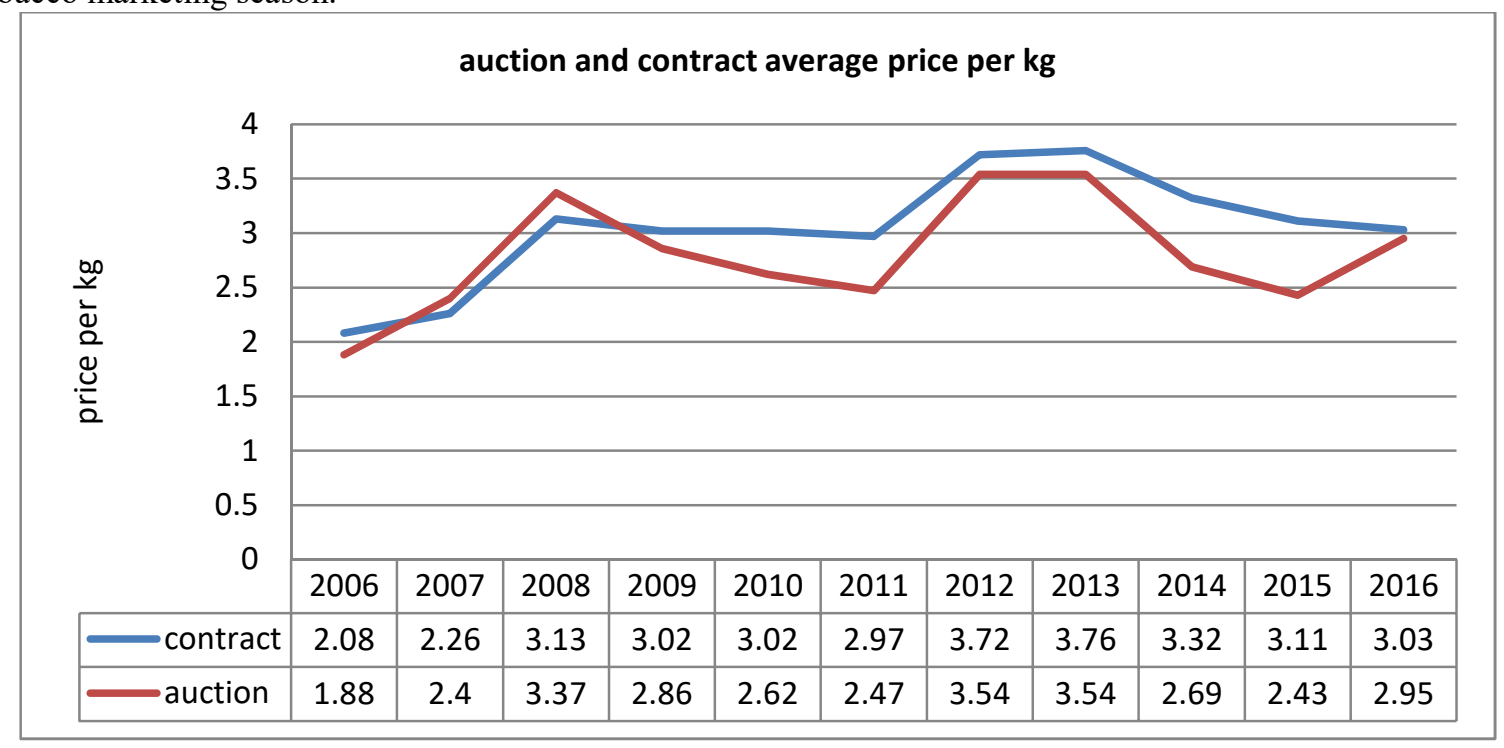

Figure 12 Price trends for tobacco sales under auction and contract marketing arrangements

Source: TIMB, 2017

The various socio-economic and institutional constraints faced by the contractors in the running of contract farming arrangements in Mt Darwin are:

i. $\quad$ Side-marketing

Side-marketing was cited as one of the major institutional constraints that was affecting tobacco marketing in Zimbabwe. The contractors also accused farmers of selling inputs or diverting the inputs provided under contract to other crops.

ii. $\quad$ High operating costs

The contractors cited high operating costs as one of the major constraints. They revealed that they were obliged to pay \$US 5000 annually to get buyers' licences from the TIMB. On the other hand rural district councils also levied them trading licences which they felt increased their operation costs.

\section{Recommendations and Conclusion}

The possible recommendations to address the shortage of foreign currency by input producers include toll manufacturing. Under toll manufacturing arrangement, the tobacco contractors with offshore lines of credit can provide input suppliers with foreign currency in exchange for inputs like fertilisers and chemicals. The contractors can thereafter advance the inputs to the farmers and recover them during the tobacco marketing process. To address the high transport, government needs to with the private sector and revitalise the rail transport. Use of the rail system is likely to lower the transport costs.

Farmers need to partner with government, tobacco contractors and banks in investing in low cost irrigation technologies in order for the farmers not to over-rely on rain-fed agriculture. Such arrangements should oblige farmers to pay for the equipment under agreed terms and conditions to enhance sustainability. Government needs to ensure that the value chain actors abide by terms of contracts to manage institutional failures like side-marketing. There should be synergies between marketers and producers to avoid undercutting of prices or of the product or total diversion of agricultural inputs to other commodities.

The challenges identified in this study require a multi-sectorial approach where the value chain stakeholders namely; input producers, farmers, tobacco companies, including chain supporters [government, transporters, financiers and insurance] collectively come together and find ways of addressing the challenges identified. The value chain approach enhances the value chain actors to collaborate and collectively find common solutions to the socio-economic and institutional bottlenecks affecting the value chain. As in paving way for development of the smallholder tobacco value chain in general, value chain approach allows value chain stakeholders to collaborate in addressing the challenges which in itself has long-term benefits to any development endeavour. When value 
chain actors enjoy collaboration, they are afforded the capacity to recover quickly from shocks and other adversities. For sustainable development of the tobacco value chain, the value chain approach assists in compelling stakeholders to be always focused on delivering value to each other and identifying areas that need to be improved.

The farmers on the other hand need to be organised into formal groups to make their voices more audible

\section{References}

Bategeka L, Kiiza J, Kasirye I (2013). Institutional Constraints to Agricultural Development In Uganda. Research Series No 100. Kampala: Makerere University Economic Policy Research Centre.

Boudi M, Laoub K, Chehat F (2016). A Value Chain Analysis for Sustainable Development of Olive Oil AgroIndustry: The case of Algeria. Journal of Agriculture and Environment for International Development. , JAEID 110. (2):267-297.

Brown D, Kilig J (1996). The Concept of Resilience. Theoretical Lessons For Community Research. Health and Canadian Society. 4 (1): 29-52.

Cloete PC (2013). Institutions and Agricultural Development: The case of the North West Province in South Africa African Journal of Agricultural Research. 8 (27):3495-3504.

Dorward AR, Kirsten JF, Poulton C, Vink N (2009). Institutions and the Agricultural Development Challenge in Africa. In J.F. Kistern, A. Dorward, C. Poulton \& N. Vink, eds. Institutional Economics Perspectives on African Agricultural Development. Washington: International Food Policy Research Institute :3-34.

Eaton D, Maijerink G, Bijman J (2008). Understanding Institutional Arrangements. In Fresh Fruit and Vegetable Value Chains in East Africa. Paper Presented at ISNIE 2008 Conference. Toronto, 2008.

Gay K, Stubbs E ( 2016). http://edis.ifas.ufl.edu. [Online] [Accessed 12 September 2018].

GOZ (2016). Zimbabwe Vulnerability Assessment Committee.. Rural Livelihoods Assessment Report. Harare: Government of Zimbabwe.

GOZ (2018). The Plant Pest Disease (Tobacco) Regulations. Statutory Instrument 711 (1979). Department of Research and Specialist Services. Plant Quarantine Services Institute. Ministry of Lands Agriculture and Rural Resettlement.

Guta T (2017). Tobacco farmers should seriously consider insuring their crop. Newspaper. Harare, Zimbabwe: Bulawayo 24.

Harder A (2013). Determining Program Priorities. University of Florida Institute of Food and Agricultural Sciences.

Kadungure S (2017). Freak storm shreds tobacco in Makoni. Newspaper. Harare: The Herald 15 November 2017 The Herald.

Kaplinsky R, Morris M (2001). A handbook for value chain research. Brighton: Institute for Development Studies.

Kawadza S (2018). http://ebusinessweekly.co.zw/zims-tobacco-industry-battles-deforestation/. [Online] [Accessed 13 August 2018].

Kirsten JF, Doward A, Poulton C, Vink N (2009). Institutional Economics. Perspectives on African Agricultural Development. Washington DC: International Food Policy Research Institute.

Lown AE, McDaniel PA, Malone RE (2016). Tobacco is "our industry and we must support it": Exploring the potential implications of Zimbabwe's accession to the Framework Convention on Tobacco Control. Globalization and Health.

Makuvaro V, Walker S, Munodawafa A, Chagonda A, Masere A, Murewi C, Mubaya C (2017). Constraints to crop production and adaptation strategies of smallholder farmers in semi arid central and western Zimbabwe. African Crop Science Journal. 25 :221-235.

Mukwereza L (2013). Reviving Zimbabwe's Agriculture: The Role of China and Brazil. Institute of Developmental Studies. Future Agricultures.

Mutambara S (2016). Agricultural input supply challenges of smallholder irrigation schemes in Zimbabwe. Journal of Development and Agricultural Economics: 260-71.

Mutambara S (2016). Smallholder irrigation farmers' financial exclusion in Zimbabwe: A resilience threat. International Journal of Agricultural Policy and Research. 4 (8):256-70.

Mutambara S, Darkoh M, Atlhopheng J (2015). Making Markets Work for the Poor (M4P) Approach and Smallholder Irrigation Farming. Department of Environmental Science. University of Botswana. 4(1):1-9.

Mwimo L, Mbowe W, Kombe C (2016). Contract Farming Schemes In Tanzania, Benefits and Challenges. Working Paper No 8. January 2016. Bank Of Tanzania.

Popp D (2013). Value Chain Development by the Private Sector in Africa. Lessons Leant and Guidance Notes. GIZ.

Prowse M, Moyer-Lee J (2013). A Comparative Value Chain Analysis of Smallholder Burley Tobacco Production in Malawi-2003/4 and 2009/10. Journal of Agrarian Change.

Ramík J (2017). Ranking Alternatives by Pairwise Comparisons Matrix and Priority Vector. Scientific Annals of Economics and Business:85-95. 
Sambuo D (2014). Tobacco Contract Farming Participation and Income in Urambo: Heckman's Selection Model. Journal of Economics and Sustainable Development: 5 ( 28):230-37.

Scoones I, Mavedzenge B, Murimbarimba F, Sukume C (2016). Tobacco, contract farming, and agrarian change inZimbabwe. Journal of Agrarian Change:22-42.

Sikwela MM, Mushunje A (2013). The Impact of Farmer Support Programs on Household Incomes and Sustainability In Smallholder Production: A Case Study of The Eastern Cape and KwaZulu Natal Farmers, South Africa. African Journal of Agricultural Research 8 (21):2502-2511.

The Herald (2016). Forex Shortages Chocking Industry Growth. Harare. 18 April 2018

TIMB (2016). Tobacco Industry and Marketing Board. Annual Statistical Report. Harare: Tobacco Industry and Marketing Board.

TIMB (2018). Preparatory Meeting for the 2018 marketing season. Harare: TIMB.

TIMB (2018). Progress of the Zimbabwe flue-cured tobacco industry. Appendix 7.10. Harare, Zimbabwe: TIMB Tobacco Industry Marketing Board.

Van Schalkwyk HD, Carstens JP, Cloete P Van Der Merwe JD (2009). Master Plan for Agriculture in North West Province. Unpublished Research Report.

Yamene T( 1967). Statistics, An Introductory Approach. New York: Harper and Row.

ZFU, 2017. Weekly Market Guide Issue No 296, 7 July 2017. Zimbabwe Farmers Union. 